\title{
Characterization of Soil Acidity under Paddy Land Use Cover of Coastal Karnataka
}

\author{
S. M. Jayaprakash*, H. M. Chidanandappa, B. C. Dhananjaya, \\ G. N. Thippeshappa, Y. Vishwanatha Shetty and M. Hanumanthappa
}

Zonal Agricultural \& Horticultural Research Station, Brahmavar, UAHS, Shivamogga, India

*Corresponding author

\section{Keywords \\ Acidity, \\ Exchangeable, \\ Paddy, Calcium and \\ Magnesium}

\section{Article Info}

Accepted:

15 September 2020

Available Online:

10 October 2020

\section{A B S T R A C T}

The study was conducted at coastal zone of Karnataka to characterize the acidity of soils and to assess calcium and magnesium status of soils under paddy land is cover. Soil samples were collected at depth of $0-15 \mathrm{~cm}$ from paddy growing areas of Dakshina Kannada and Udupi districts. The collected soil sample were processed and analyzed to know the physical and chemical properties of soil, the nature of soil acidity and the status of exchangeable calcium and magnesium in soils. The result from the present investigation revealed that active acidity was ranged from $2.19 \times 10^{-6}$ to $8.9 \times 10^{-5} \mathrm{~mol} \mathrm{H}^{+} \mathrm{L}^{-1}$, exchangeable acidity was in the range of 0.401 to $5.959 \mathrm{cmol}\left(\mathrm{p}^{+}\right) \mathrm{kg}^{-1} \mathrm{~g}, \mathrm{pH}$ dependent acidity varied from 3.000 to $49.875 \mathrm{cmol}\left(\mathrm{p}^{+}\right) \mathrm{kg}^{-1}$ and the total potential acidity which included both exchangeable and $\mathrm{pH}$ dependent acidity ranged from 4.98 to $50.818 \mathrm{cmol}$ $\left(\mathrm{p}^{+}\right) \mathrm{kg}^{-1}$. From the investigation we came to know that more than 99.9 per cent of the total acidity in soils was found to be in the form of potential acidity and out of which nearly 8 per cent was in the form of exchangeable acidity. However, the order of distribution of different forms of acidity was found to be as follows; $\mathrm{pH}$ dependent acidity $>$ Exchangeable acidity> Active acidity.

\section{Introduction}

Soil acidity is one of the factors affecting the availability of $\mathrm{Ca}$ and $\mathrm{Mg}$ in soils. Availability of $\mathrm{Ca}$ and $\mathrm{Mg}$ in soils decreases with increase in acidity of soil. Because of low status in exchangeable $\mathrm{Ca}$ and $\mathrm{Mg}$ and other acid related problems, the productivity of acid soil found to be low.

The soil which is subjected to heavy rainfall resulting in leaching of nutrients such as potassium, calcium and magnesium and accumulation of oxides of $\mathrm{Al}$ and Fe lead to poor soil fertility and low $\mathrm{pH}$. Balasubramanian and Raj (1969) reported that among the different forms of phosphate in laterite soils $\mathrm{Fe}$ and $\mathrm{Al}$ phosphate occupied major portion than $\mathrm{Ca}$ phosphate in those soils.

Owing to low availability of $\mathrm{Ca}$ and $\mathrm{Mg}$ in acid soils due to soil acidity related problems such as leaching loss of bases and high 
concentration of exchangeable $\mathrm{Al}$ and low CEC, the productivity of acid soil is found to be low (Craswell and Pushparajah, 1989). Similarly, Haynes and Ludecke (1981) reported that both soluble and exchangeable $\mathrm{Ca}$ decreased with decreasing soil $\mathrm{pH}$. Further, at low $\mathrm{pH}$, the bioavailability of $\mathrm{Ca}$ was retarded by high concentration of $\mathrm{Al}$. Similarly, low CEC and high saturation of Fe and $\mathrm{Al}$ in acid soils, magnesium remained in soil solution and subjected for leaching loss (Edmeades et al., 1985; Myers et al., 1988). Therefore, it is understood that in highly weathered soils the availability of $\mathrm{Ca}$ and $\mathrm{Mg}$ is insufficient for crop production. Hence, it is very much essential to supply $\mathrm{Ca}$ and $\mathrm{Mg}$ in the form of liming material to overcome the problems of acid soils and also to increase their production potential.

The area of Coastal zone of Karnataka comprised of $1.17 \mathrm{~m}$. ha which covers areas of Uttar Kannada, Udupi and Dakshina Kannada districts. The annual rainfall ranges from 3010.9 to $4694.4 \mathrm{~mm}$, of which 80 per cent is received during the months of May to October. The elevation of land ranges from 300 to 800 meters. The soils are red lateritic and coastal alluvial and belong to Ultisols order. The Major crops grown in this zone are paddy, coconut and areca nut, cashew, pulses, rubber, groundnut and vegetables. Paddy is generally cultivated in three seasons in a year, Karthika or Yenel (May - October), Suggi (October to January) and Kolake (January to April).

\section{Materials and Methods}

The present investigation involved a soil survey to know physical and chemical properties, the nature of soil acidity and the status of exchangeable calcium and magnesium in soils under paddy cover of Coastal Karnataka. As a part of the investigation, a survey was conducted to assess the physical and chemical properties, distribution of different forms of acidity and exchangeable calcium and magnesium status in soil for this 60 and 100 (Total 160) surface soil samples $(0-15 \mathrm{~cm}$ depth) were collected from soils coming under paddy growing areas of Dakshina Kannada and Udupi districts of coastal Karnataka, respectively. The collected samples were processed in the laboratory and preserved for further analysis (Table 1 and 2).

\section{Results and Discussion}

Correlation matrix observed between soil physical, chemical properties and forms of acidity in soils paddy cover of Coastal Karnataka

\section{Soil physical properties}

From the present investigation it was found that sand had a positive correlation with active acidity $(\mathrm{r}=0.146)$ and negative and significantly correlated with silt $(\mathrm{r}=$ $0.429 * *)$, clay $(\mathrm{r}=-0.652 * *)$, exchangeable acidity $\left(\mathrm{r}=-0.224^{* *}\right), \mathrm{pH}$ dependent acidity $(\mathrm{r}$ $=-0.199 *)$, potential acidity $(\mathrm{r}=-0.224 * *)$, EC $\left(\mathrm{r}=-0.214^{* *}\right)$, organic carbon $(\mathrm{r}=-$ $\left.0.188^{*}\right)$, CEC $\left(\mathrm{r}=-0.556^{* *}\right)$, exchangeable calcium $\left(\mathrm{r}=-0.200^{*}\right)$ and exchangeable magnesium $(\mathrm{r}=-0.370 * *)$.

Silt had a positive and significantly correlation with active acidity $(\mathrm{r}=0.301 * *)$ and positively correlated with exchangeable calcium $(r=0.045)$ and negatively and significantly correlated with clay $(\mathrm{r}=$ $\left.0.406^{* *}\right)$, exchangeable acidity $(\mathrm{r}=-0.192 *)$, $\mathrm{pH}$ dependent acidity $(\mathrm{r}=-0.219 * *)$, potential acidity $(\mathrm{r}=-0.237 * *)$, organic carbon $(\mathrm{r}=-$ $\left.0.282^{* *}\right)$, CEC $\left(\mathrm{r}=-0.185^{*}\right)$ and negatively correlated with EC $(\mathrm{r}=-0.106)$ and exchangeable magnesium $(r=-0.031)$.

Clay positively and significantly correlated with exchangeable acidity $\left(\mathrm{r}=0.388^{* *}\right), \mathrm{pH}$ 
dependent acidity $\left(\mathrm{r}=0.385^{* *}\right)$, potential acidity $\left(\mathrm{r}=0.425^{* *}\right)$, $\mathrm{EC}\left(\mathrm{r}=0.305^{* *}\right)$, organic carbon $(\mathrm{r}=0.427 * *), \mathrm{CEC}(\mathrm{r}=$ $\left.0.718^{* *}\right)$, exchangeable calcium $\left(\mathrm{r}=0.165^{*}\right)$ and exchangeable magnesium $\left(\mathrm{r}=0.400^{* *}\right)$ and negative and significantly correlated with active acidity $\left(\mathrm{r}=-0.400^{* *}\right)$.

\section{Soil chemical properties}

\section{Active acidity}

Active acidity had a positive and significantly correlation with exchangeable calcium ( $\mathrm{r}=$ $\left.0.263^{* *}\right)$ and positively correlated with exchangeable magnesium $(\mathrm{r}=0.044)$, negative and significantly correlated with exchangeable acidity $(\mathrm{r}=-0.540 * *)$, potential acidity $(\mathrm{r}=-0.201 *)$, EC $\left(\mathrm{r}=-0.315^{* *}\right)$, organic carbon $(\mathrm{r}=-0.440 * *)$ and CEC $(\mathrm{r}=-$ $\left.0.471^{* *}\right)$ and negatively correlated with $\mathrm{pH}$ dependent acidity $(r=-0.117)$.

\section{Exchangeable acidity}

Exchangeable acidity had a positive and significant correlation with $\mathrm{pH}$ dependent acidity $\left(\mathrm{r}=0.310^{* *}\right)$, potential acidity $(\mathrm{r}=$ $0.459 * *)$, organic carbon $(\mathrm{r}=0.433 * *)$ and CEC $(r=0.724 * *)$, positively correlated with EC $(r=0.081)$, negative and significantly correlated with exchangeable calcium ( $\mathrm{r}=$ $0.488 * *)$ and negatively correlated with exchangeable magnesium $(r=-0.146)$.

\section{Soil reaction $(\mathrm{pH})$}

pH dependent acidity had a positive and significantly correlation with potential acidity $\left(\mathrm{r}=0.987^{* *}\right)$, organic carbon $\left(\mathrm{r}=0.391^{* *}\right)$, CEC $\left(\mathrm{r}=0.316^{* *}\right)$, positively correlated EC $(r=0.002)$, with exchangeable magnesium $(r$ $=0.002$ ) and negatively correlated with exchangeable calcium $(\mathrm{r}=-0.045)$. Potential acidity had a positive and significant correlation organic carbon $\left(\mathrm{r}=0.438^{* *}\right)$ and
CEC $\left(\mathrm{r}=0.418^{* *}\right)$, positively correlated with EC $(r=0.016)$ and negatively correlated with exchangeable calcium $(\mathrm{r}=-0.125)$ and exchangeable magnesium $(\mathrm{r}=-0.023)$.

\section{Electrical conductivity}

Electrical conductivity had a positive and significantly correlation with CEC ( $\mathrm{r}=$ $0.232 * *)$ and positively correlated with organic carbon $(\mathrm{r}=0.134)$, exchangeable calcium $(\mathrm{r}=0.148)$ and exchangeable magnesium $(r=0.090)$. Organic carbon had a positive and significantly correlation with CEC $\left(r=0.391^{* *}\right)$, positively correlated with exchangeable magnesium $(r=0.095)$ and negative and significant correlation with exchangeable calcium $\left(\mathrm{r}=-0.186^{*}\right)$.

CEC had a positive and significant correlation with exchangeable magnesium $(\mathrm{r}=0.389 * *)$ and positively correlated with exchangeable calcium $(r=0.043)$. Exchangeable calcium had a positive and significant correlation with exchangeable magnesium $\left(r=0.205^{*}\right)$.

The results of above study indicates that Udupi and Dakshina Kannada districts active acidity in the soils of Udupi and Dakshina Kannada districts is ranged from $2.19 \times 10^{-6}$ to $8.9 \times 10^{-5} \mathrm{~mol} \mathrm{H}^{+} \mathrm{L}^{-1}$, exchangeable acidity was in the range of 0.401 to $5.959 \mathrm{cmol}\left(\mathrm{p}^{+}\right)$ $\mathrm{kg}^{-1} \mathrm{~g}, \mathrm{pH}$ dependent acidity varied from 3.000 to $\left.49.875 \mathrm{cmol}^{+} \mathrm{p}^{+}\right) \mathrm{kg}^{-1}$ and the total potential acidity which included both exchangeable and $\mathrm{pH}$ dependent acidity ranged from 4.98 to $50.818 \mathrm{cmol}\left(\mathrm{p}^{+}\right) \mathrm{kg}^{-1}$.

Therefore, it was understood that more than 99.9 per cent of the total acidity in soils was found to be in the form of potential acidity and out of which nearly 8 per cent was in the form of exchangeable acidity. 
Table.1 Correlation matrix (' $r$ ' values) recorded between exchangeable calcium and magnesium, soil properties and forms of acidity in soils under paddy cover of Coastal Karnataka

\begin{tabular}{|c|c|c|c|c|c|c|c|c|c|c|c|c|}
\hline & Sand & Silt & Clay & $\begin{array}{c}\mathbf{A A} \\
(\mathbf{p H})\end{array}$ & EA & pH DA & PA & EC & OC & CEC & $\mathrm{Ex} \cdot \mathrm{Ca}^{2+}$ & $\mathrm{Ex} \cdot \mathrm{Mg}^{2+}$ \\
\hline Sand & 1.000 & & & & & & & & & & & \\
\hline Silt & $-0.429 * *$ & 1.000 & & & & & & & & & & \\
\hline Clay & $-0.652 * *$ & $-0.406^{* *}$ & 1.000 & & & & & & & & & \\
\hline $\mathbf{A A}(\mathbf{p H})$ & 0.146 & $0.301 * *$ & $-0.400 * *$ & 1.000 & & & & & & & & \\
\hline EA & $-0.224 * *$ & $-0.192 *$ & $0.388 * *$ & $-0.540 * *$ & 1.000 & & & & & & & \\
\hline pH DA & $-0.199 *$ & $-0.219 * *$ & $0.385^{* *}$ & -0.117 & $0.310 * *$ & 1.000 & & & & & & \\
\hline PA & $-0.224 * *$ & $-0.237 * *$ & $0.425^{* *}$ & $-0.201^{*}$ & $0.459 * *$ & $0.987 * *$ & 1.000 & & & & & \\
\hline EC & $-0.214 * *$ & -0.106 & $0.305^{* *}$ & $-0.315^{* *}$ & 0.081 & 0.002 & 0.016 & 1.000 & & & & \\
\hline OC & $-0.188^{*}$ & $-0.282 * *$ & $0.427 * *$ & $-0.440 * *$ & $0.433 * *$ & $0.391 * *$ & $0.438 * *$ & 0.134 & 1.000 & & & \\
\hline CEC & $-0.556^{* *}$ & $-0.185^{*}$ & $0.718 * *$ & $-0.471 * *$ & $0.724 * *$ & $0.316^{* *}$ & $0.418 * *$ & $0.232 * *$ & $0.391 * *$ & 1.000 & & \\
\hline Ex. $\mathrm{Ca}^{2+}$ & $-0.200^{*}$ & 0.045 & $0.165^{*}$ & $0.263 * *$ & $-0.488 * *$ & -0.045 & -0.125 & 0.148 & $-0.186^{*}$ & 0.043 & 1.000 & \\
\hline Ex. $\mathrm{Mg}^{2+}$ & $-0.370 * *$ & -0.031 & $0.400 * *$ & 0.044 & -0.146 & 0.002 & -0.023 & 0.090 & 0.095 & $0.389 * *$ & $0.205^{*}$ & 1.000 \\
\hline
\end{tabular}

(Note:AA: Active Acidity (pH) EA: Exchangeable Acidity,

pH DA: pH Dependant Acidity PA: Potential acidity, EC: Electrical Conductivity, OC: Organic carbon, CEC: Cation Exchange Capacity)

Table.2 Exchangeable calcium and magnesium Status (deficient \& sufficient) in soils under paddy cover in Coastal Karnataka

\begin{tabular}{|c|c|c|c|}
\hline District & Udupi & Dakshina Kannada & Total \\
\hline \multicolumn{4}{|l|}{ Calcium } \\
\hline Total no. of samples analysed & 100 & 60 & 160 \\
\hline No. of samples recorded above the critical limit of calcium & $46(46.0 \%)$ & $20(33.33 \%)$ & $66(41.25 \%)$ \\
\hline No. of samples recorded below the critical limit of of calcium & $54(54.0 \%)$ & $40(66.67 \%)$ & $94(58.75 \%)$ \\
\hline \multicolumn{4}{|l|}{ Magnesium } \\
\hline Total no. of samples analysed. & 100 & 60 & 160 \\
\hline No. of samples recorded above the critical limit of of magnesium & $44(44.0 \%)$ & $22(36.67 \%)$ & $66(41.25 \%)$ \\
\hline No. of samples recorded below the critical limit of magnesium & $56(56.0 \%)$ & $38(63.33 \%)$ & $94(58.75 \%)$ \\
\hline
\end{tabular}

[Note: Critical limits of exch. $\mathrm{Ca}^{2+}$ and $\mathrm{Mg}^{2+}$ in soils are 2.00 and 0.5 meq $100 \mathrm{~g}$, respectively.

(Fundamentals of Soil Science, Published by ISSS)] 
However, the order of distribution of different forms of acidity was found to be as follows; $\mathrm{pH}$ dependent acidity > Exchangeable acidity $>$ Active acidity. High potential acidity in soils may be attributed to the soils are dominated with $\mathrm{Fe}$ and $\mathrm{Al}$ oxides, kaolinite minerals and medium to high in organic matter status. The above materials saturated with $\mathrm{H}^{+}$and $\mathrm{Al}^{3+}$ ions in exchangeable and non exchangeable forms. Further, it is known that the potential acidity is in a dynamic equilibrium with active acidity in soils as a result the $\mathrm{pH}$ of soils was found to be low due to high active acidity in soils (Dolui and Sarkar 2001, Arunima et al., 2012 and Chimdi et al., 2012)

In conclusion,

The exchangeable $\mathrm{Ca}$ status in soils ranged from 0.58 to $3.86 \mathrm{cmol}\left(\mathrm{p}^{+}\right) \mathrm{kg}^{-1}$ with a mean of $1.88 \mathrm{cmol}\left(\mathrm{p}^{+}\right) \mathrm{kg}^{-1}$ and exchangeable $\mathrm{Mg}$ varied from 0.02 to $2.59 \mathrm{cmol}\left(\mathrm{p}^{+}\right) \mathrm{kg}^{-1}$ with a mean of $0.54 \mathrm{cmol}\left(\mathrm{p}^{+}\right) \mathrm{kg}^{-1}$ Further, out of 160 samples analyzed for exchangeable $\mathrm{Ca}$ and $\mathrm{Mg}, 68.75$ per cent samples recorded the exchangeable $\mathrm{Ca}$ below critical limit (2.0 cmol $\left.\left(\mathrm{p}^{+}\right) \mathrm{kg}^{-1}\right)$. Similarly, 48.75 per cent samples recorded the exchangeable Mg status below the critical limit of $\mathrm{Mg}\left(0.5 \mathrm{cmol}\left(\mathrm{p}^{+}\right)\right.$ $\left.\mathrm{kg}^{-1}\right)$.

Soils were fractionated for different forms of acidity and their distribution in soils whereas follows; Active acidity ranged from $2.19 \times 10^{-}$ ${ }^{6}$ to $8.9 \times 10^{-5} \mathrm{~mol} \mathrm{H}^{+} \mathrm{L}^{-1}$, exchangeable acidity was in the range of 0.401 to 5.959 cmol $\left(\mathrm{p}^{+}\right) \mathrm{kg}^{-1}, \mathrm{pH}$ dependent acidity varied from 3 to $49.875 \mathrm{cmol}\left(\mathrm{p}^{+}\right) \mathrm{kg}^{-1}$ and total potential acidity which includes exchangeable and $\mathrm{pH}$ dependent acidity ranged from 4.98 to $50.818 \mathrm{cmol}\left(\mathrm{p}^{+}\right) \mathrm{kg}^{-1}$. Therefore, it was noticed that more than 99.9 per cent of the total acidity in soils was found to be in the form of potential acidity and out of which nearly 8 percent was in the form of exchangeable acidity. However, the order of their distribution in soils was found to be as follows; $\mathrm{pH}$ dependent acidity > Exchangeable acidity > Active acidity.

\section{References}

Arunima, G., Talukdar, M. C. and Ananta Dutta, 2012, Physico-chemical characteristics of acid soils of Amguri block in Sivasagar district, Assam. In; Compendium of Abstracts, $8^{\text {th }}$ PSILPH, UAS, Bangalore: Pp. 39-40.

Balasubramanian, V. and Raj, D., 1969, Study of the forms of soil $\mathrm{P}$ in Tamil Nadu. Madras Agric. J., 56: 790-793.

Chimdi, A., Gebrekidan, A., Kibret, K. and Tadesse, A., 2012, Effects of Liming on acidity-related chemical properties of soils of different land use systems in Western Oromia, Ethiopia. World $J$. Agric. Sci., 8(6): 560-567.

Craswell, E. T. and Pushparajah, E., 1989, Management of acid soils in the Humid Tropics of Asia. Australian Centre for Int. Agric. Res (ACIAR) Monograph No.13 (mSRAM Monograph No.1), $118 \mathrm{p}$.

Dolui, A. K. and Sarkar, R., 2001, Influence of nature of acidity onlime requirement of two Inceptisol and an Alfisol. J. Indian Soc. Soil Sci., 49: 195-198.

Edmeades, D. C., Wheeler, D. M. and Crouchley, G., 1985, Effects of liming on soil magnesium on some soils in New Zealand. Commun. Soil Sci. Plant Anal., 16: 727-739.

Haynes, R. J. and Ludecke, T. E., 1981, Effect of lime and phosphorus applications on concentrations of available nutrients and on $\mathrm{P}, \mathrm{Al}$ and $\mathrm{Mn}$ uptake by 2 pasture legumes in an acid soil. Pl. Soil. 62: 117128.

Myers, J. A., Mclean, E. O. and Bingham, J. M., 1988, Reductions in exchangeable magnesium with liming acid Ohio soils. Soil Sci. Soc. Am. J., 52: 131-136. 
How to cite this article:

Jayaprakash, S. M., H. M. Chidanandappa, B. C. Dhananjaya, G. N. Thippeshappa, Y. Vishwanatha Shetty and Hanumanthappa, M. 2020. Characterization of Soil Acidity under Paddy Land Use Cover of Coastal Karnataka. Int.J.Curr.Microbiol.App.Sci. 9(10): 1879-1884. doi: https://doi.org/10.20546/ijcmas.2020.910.230 